\title{
Олександр ПОТЕХІН,
}

доктор історичних наук, головний науковий співробітник ДУ «Інститут всесвітньої історії НАН України»

\section{МІЖНАРОДНИЙ КОНТЕКСТ ВІЙН У КОЛИШНІЙ СФРЮ (1991-1995 рр.)}

Анотація. У статті охарактеризовано причини югославської трагедії, під час якої загинуло близько трьохсот тисяч та стали біженцями більше двох млн людей. Автор підкреслює, що врегулювання югославської кризи мало стати справою НАТО. Тоді американці та європейці змогли 6 почати працювати разом як посередники з різними сторонами конфлікту для забезпечення мирного процесу «розірвання шлюбів» між республіками. Автор стверджує, якщо введення миротворчого міжнародного контингенту до окупованих Російською Федерацією окремих районів Донецької та Луганської областей України набуде реальних контурів, Києву потрібно найретельнішим чином вивчити фактичний бік подій в колишній СФРЮ. Це мало 6 допомогти уникнути багатьох ускладнень, які виникали в процесі здійснення операції з примушення до миру на Балканах у першій половині 90-х років XX століття.

Ключові слова: НАТО, Балкани, СФРЮ, югославська трагедія, США

Війни в Югославії розпочалися внаслідок економічного й політичного занепаду СФРЮ протягом 1980-х років. Результатом тривалої кризи югославської національної, федеральної та економічної політики, яка невпинно поглиблювалася, став розпад держави. Словенія та Хорватія заявили про вихід зі складу федерації влітку 1991 р., а Боснія-Герцеговина та Македонія - взимку 1991-1992 років. У складі «колишньої Югославії» (невизнаної ФРЮ) залишилися Сербія, Воєводина, Чорногорія та Косово - усі під владою Сербії та ії президента, новоявленого великосербського націоналіста з корінням комуністичного функціонера С. Милошевича. Розподіл республік СФРЮ відбулося далеко не мирним шляхом. Збройні конфлікти між сербами та хорватами, сербами та боснійцями (мусульманами), сербами та косоварами (албанцями Косова), боснійцями та хорватами було позначено проявами нелюдської жорстокості з боку всіх сто- 
рін-учасниць війн на території колишньої СФРЮ, включно з масовими позасудовими вбивствами цивільних і полонених, тортурами, гвалтуваннями та пограбуваннями, тактикою «випаленої землі», витісненням сотень тисяч людей із домівок, місцевостей, де їхні пращури мешкали століттями, усього того, що дістало політкоректну назву «етнічні чистки» [1].

Багато публікацій, присвячених проблемі невтручання/втручання США/НАТО у війни в колишній СФРЮ, залишають враження, що громадянська війна була неминучою. Найбільш відома з англомовних розвідок, присвячених регіону, - книга подорожніх заміток Р. Вест «Чорне ягня та сірий сокіл» [2] - побачила світ 1941 року і кілька разів була перевидана. Однобічно просербські підходи Р. Вест та її думка про те, що «мусульмани як раса були чужинцями» на Балканах, вплинули на кілька поколінь західних політиків [3]. Так багато хто намагався виправдати своє небажання або нездатність розв'язувати проблеми Балкан. До них належав, зокрема, колишній посол США в Югославії, заступник державного секретаря Л. Іглбергер. Він регулярно засуджував американських політиків, які закликали до активних дій. У вересні 1992 року, наприклад, уже після того, як журналісти вперше задокументували скоєні сербами звірства проти мусульман у концентраційних таборах у західній Боснії, Л. Іглбергер заявив: «Я казав це 38000 разів, і я повинен це також сказати людям цієї країни [США]. На часі всім зрозуміти: ця трагедія - не те, що може бути вирішено ззовні. Допоки боснійці (мусульмани. - Авт.), серби та хорвати не вирішать перестати вбивати один другого, зовнішній світ не зможе нічого зробити» [4, р. 52]. Послідовно різко був проти втручання Вашингтона в югославські справи патріарх політичного реалізму, теж колишній посол США в Белграді Дж. Кеннан [5, р. 34].

Чому сталася югославська трагедія, під час якої загинуло приблизно 300 тис. та стали біженцями понад 2 млн людей? Простої відповіді на це запитання марно шукати. На час початку війн у колишній СФРЮ склалася досить складна ситуація у відносинах між державами - членами Північноатлантичного альянсу, які після втрати головного ворога - СРСР та розпаду Організації Варшавського Договору по-різному оцінювали майбутнє НАТО або зовсім, у річищі політичного реалізму, не бачили перспектив Альянсу. Також методом спроб та помилок будувалася практична співпраця НАТО й ООН, що так і не стала «історією успіху». 3 боку НАТО операції в колишній СФРЮ далеко виходили за межі проголошеної у Вашингтонському договорі 1949 року мети «захисту Північноатлантичного регіону».

Через югославські події в Європі відбувалося руйнування мирного «нового світового порядку», за визначенням президента Дж. Буша-старшого. Останній посол США у СФРЮ В. Зіммерман у середині 90-х років рефлексував: «Відмова адміністрації Буша вже на початку використати амери- 
канську силу було нашою найбільшою помилкою у всій югославській кризі. Це зробило неминучим несправедливий результат і втрату понад ста тисяч життів» [6, р. 216]. США, НАТО, ООН та ОБСЄ обрали хибну позицію підтримувати те, чого не було - миру в колишній СФРЮ. Головними фігурами у формуванні неополітики США/НАТО щодо Югославії були державний секретар в адміністрації президента Дж. Буша Дж. Бейкер, його заступник (згодом - очільник держдепу), посол у СФРЮ за часів Й.-Б. Тіто Л. Іглбергер і радник із національної безпеки Б. Скоукрофт (на початку своєї кар'єри у ВПС США - військовий аташе в Белграді). Вони представляли так зване «просербське лобі» в адміністрації Дж. Буша, яке підтримувало територіальну цілісність Югославії в кордонах колишньої СФРЮ та програму економічних реформ А. Марковича (iї швидко поховав С. Милошевич) [7, p.149].

18 червня 1991 року на конференції Інституту Аспена в Берліні державний секретар США Дж. Бейкер висунув вимогу до членів Організації 3 безпеки і співпраці в Європі (ОБСЄ) зробити все можливе для збереження цілісності держав Східної Європи. Через три дні в Белграді він продемонстрував, що в нього немає чого запропонувати Югославії, окрім ідеї збереження ії як об’єднаної демократичної держави (аналогічно з СРСР), та закликав лідерів окремих республік продовжити переговори з розширення сфер їх повноважень. Бейкер запевнив Милошевича: Сполучені Штати не визнають незалежність Словенії чи Хорватії [8, p.155].

Позиція Бейкера відрізнялася однозначністю: «У цій бійці нашого собаки немає». Уперше після Другої світової війни Вашингтон цілком переклав головну проблему безпеки в Європі власне на європейців. У своїх мемуарах Бейкер пояснює свою позицію: «На часі було європейцям [...] показати, що вони можуть виступати як єдина сила. Югославія була таким найкращим першим тестом» [9, р. 637]. Насправді, на думку Р. Холбрука, Югославія була найгіршим місцем для «першого випробування нової американської політики європейське - європейцям» [4, р. 57]. Звичайно, зі зникненням радянської загрози та об’єднанням Німеччини потенційно роль Європи в євроатлантичному партнерстві, як того хотіли й самі європейці, мала зростати. Але протягом півстоліття Європа виявляла нездатність діяти як єдина міжнародна сила без американського керівництва. Політика адміністрації Дж. Буша в 1989-1990 роках з об’єднання Німеччини постала одним із найяскравіших досягнень зовнішньої політики США протягом XX ст. Без наполегливої та далекоглядної допомоги Вашингтона, з огляду на позиції Великої Британії та Франції, цього 6 не сталося. Проте лише через якийсь рік ті самі урядовці, які зробили можливим прорив до єдиної Німеччини, повернулися спиною до першого ж безпекового виклику в «нерозділеній» Європі. Врегулювання югос- 
лавської кризи мало стати справою НАТО. Альянс міг негайно застерегти всіх їі учасників, що повітряні сили НАТО буде застосовано проти будь-якої сторони, яка вдасться до етнічних чисток. Тоді американці та європейці змогли б почати працювати разом як посередники з різними сторонами конфлікту для забезпечення мирного процесу «розірвання шлюбів» між республіками. Але Вашингтон не захотів цього побачити. Ставлення США до югославської кризи у 1990-1992 роках підважило засади задекларованої політики щодо центральної ролі НАТО в Європі після холодної війни, яка передбачала відповідальність Альянсу щодо врегулювання конфлікту на Балканах [10, p. 127-128].

Європа також прорахувалася. Лідери Європейського Співтовариства (1-го листопада 1993 року трансформованого в Європейський Союз) урочисто задекларували: «Пробила година Європи». Водночас бажання Дж. Бейкера зберегти Сполучені Штати осторонь югославських справ, утриматися «на відстаніпростягнутоїруки» було таким сильним,щодержавнийдепартамент відмовився навіть спрямувати спостерігача на перші переговори між сторонами конфлікту, які спонсорували європейці, побоюючись, що навіть такий незначний крок може бути розцінений як потенційна можливість американського втручання. Позиції Європи та США, а в результаті й НАТО виявилися помилкою. Європа спочатку самовпевнено вважала, що зможе розв’язати проблеми Югославії без залучення США й НАТО, а Вашингтон волів після закінчення холодної війни полишити Югославію на відповідальність європейців. Знадобилися довгих і кривавих чотири роки, щоби почати виправляти ці прорахунки.

У червні 1991 року державний секретар США Дж. Бейкер здійснив свій єдиний за увесь час перебування в Білому домі президента Дж. Буша бліц-візит до Белграда, що тривав один день - між важливою зустріччю з радянськими чиновниками в Берліні з питань об'єднання Німеччини та емоційною поїздкою до Албанії, де на вулицях Тирани його вітав натовп у мільйон албанців. Сприйняття Бейкером ситуації зафіксовано в особистій доповіді з Белграда президенту Дж. Бушу наступної ночі: «Моє відчуття полягає в тому, що не варто розпочинати серйозний діалог про майбутнє Югославії, поки всі сторони краще не усвідомлять його нагальність та [наявні] небезпеки. Нам, можливо, не вдалося довести югославам своє бачення ситуації. Але ми та інші повинні продовжувати цю роботу» [9, p. 483].

Югославська народна армія (ЮНА) вдалася до вторгнення до Словенії, щоби «зберегти ії в складі федерації». (Словенія заявила про вихід зі складу СФРЮ за результатами референдуму, проведеного ще 1990 року). Після десятиденної війни (25 червня - 4 липня 1991 року), за незначних жертв з обох сторін, С. Милошевич наказав ЮНА відступити. Через кілька днів на зустрічі на о. Бріоні голландський міністр закордонних справ Ханс ван 
ден Брук, провідний європейський представник, та сторони конфлікту домовилися про угоду. Словенія погодилася дещо відтермінувати проголошення незалежності. Як вважають Л. Сільбер та А. Літл, «Угода Бріоні була визнана тріумфом європейської дипломатії. Це не мало нічого спільного $з$ дійсністю. Жодна з проблем не була вирішена ... Дипломатичний тріумф належав Милошевичу та [президенту Словенії Мілану] Кукану, які домовилися про вихід Словенії з федерації ... і фактично зруйнували федеративну Югославію» [11, p. 166 ]. Угода Кукана-Милошевича показала тактичну гнучкість і дипломатичну майстерність сербського лідера і стала в нагоді для його довгострокових, неочевидних тоді цілей. Вихід Словенії з федерації мав полегшити Милошевичу створення Югославії, у якій домінують серби, оскільки зі складу СФРЮ вийшла республіка, де ïх майже не було. Три інші війни - між хорватами та сербами, сербами та боснійцями (мусульманами), хорватами та боснійцями слідували за Бріонською угодою.

Белград розпочав другу війну - «проти сецесії Хорватії», щоби зупинити iï рух до створення самостійної держави, або принаймні встановити контроль над населеною сербами частиною республіки. Перша активна фаза війни в Хорватії випала на серпень 1991 - січень 1992 року Разом із ЮНА сербські парамілітарні підрозділи в Хорватії були за збереження населених сербами земель (країв) у складі федерації під орудою С. Милошевича та очищення від інших місцевих народів сербських етнічних районів для можливого подальшого їх об'єднання в складі «великої Сербії».

Рада Безпеки (РБ) ООН резолюцією № 713 від 25.09.1991 закликала всі сторони протистояння негайно припинити вогонь, запропонувала спрямувати міжнародних спостерігачів для контролю за виконанням цієї вимоги, декларувала, що не визнає жодних територіальних змін, досягнутих застосуванням сили, а не за згодою сторін через переговори, та увела повне ембарго на постачання зброї та обладнання військового призначення [12]. Це на практиці грало на руку сербам, тому що Белград контролював майже всі запаси озброєнь та велику частку збройового виробництва колишньої СФРЮ. С. Милошевич мав велику перевагу в повітрі - ВПС, ППО та у важких озброєннях - артилерії тощо. П. Вулфовіц, заступник міністра оборони США, безрезультатно боровся проти ембарго, охарактеризувавши це рішення як «абсолютно катастрофічно одностороннє за своїми наслідками» [4, р. 64].

Тим часом успішний наступ сербів у Хорватії тривав, вони захопили більшу частину території та загрожували Загребу. Було встановлено схему, притаманну всім війнам до кінця літа 1995 року - артилерія та авіація ЮНА підтримувала піхоту, яка складалася з частин регулярної армії та місцевих сербських добровольців [11, р.171-172]. 
Розглянувши різні варіанти, Брюссель $(€ C)$ запросив колишнього міністра закордонних справ Великої Британії лорда Каррінгтона взяти на себе місію зі встановлення миру в Югославії. Каррінгтон пізніше розповідав Р. Холбруку, що він ніколи в житті не зустрічав таких страшенних брехунів, як на Балканах [4, p. 64]. Це робило марними всі домовленості, не підкріплені силовими діями.

Початок місії Венса-Каррінгтона припав на момент, коли Європейське співтовариство готувало одне з найбільш ризикованих рішень - визнання незалежної Хорватії. Протягом кількох місяців Німеччина тиснула на своїх союзників із НАТО з вимогою зробити цей крок. С. Венс і лорд Каррінгтон рішуче були проти. Вони попереджали свого колегу Г.-Д. Геншера в різкій формі - наскільки це є допустимим у дипломатії: визнання Хорватії негайно спричинить ланцюгову реакцію й неминуче призведе до війни в Боснії. Щойно Боснія проголосить незалежність, прогнозували Венс та Каррінгтон, чисельна сербська меншина в ній повстане проти перспективи жити в державі, де домінують мусульмани. Взагалі в кожній великій етнічній групі в колишній СФРЮ гостро постало питання: «Чому ми повинні бути меншиною у вашій державі, коли ви можете бути меншиною у нашій?». Г.-Д. Геншер проігнорував такі попередження. Під час вирішального засідання міністрів закордонних справ у Брюсселі в середині грудня 1991 р. він загрожував «паузою в європейській єдності». Парадоксально, що це відбувалося тоді, коли щойно в Маастрихтському договорі, рушієм якого був канцлер Німеччини Г. Коль, було проголошено «світанок нової, єдиної Європи» [4, р. 64]. Сполучені Штати суто формально заявили про незгоду з рішенням «об’єднаних європейців» визнати Хорватію. Як зазначив Дж. Бейкер у своїх мемуарах, «наша головна увага в найближчі місяці була зосереджена на врегулюванні мирного розпуску СРСР» [9, р. 637]. I, додамо, забезпеченні правонаступництва Російської Федерації Радянському Союзу та ядерного роззброєння України, Білорусі й Казахстану. Політика Німеччини в хорватському питанні була помилкою, оскільки не супроводжувалася превентивними заходами із запобігання подальшому розвиткові подій «за гіршим сценарієм». Але покладати відповідальність за це виключно на Берлін немає підстав.

$\mathrm{OOH}$ не надто поспішала з прямим втручанням у конфлікт. У резолюції РБ № 724 від 15.12.1991 констатовано, що «умови для початку операції з підтримання миру відсутні» та висловлювалася готовність «спрямувати до Югославії невелику групу співробітників, включно з військовим персоналом, як продовження місії особистого представника Генсека ООН для здійснення підготовчих заходів для можливого розгортання операції з підтримання миру» [13]. Врешті створення таких сил (UNPROFORЮНПРОФОР) передбачено резолюцією РБ № 743 тільки від 21.02.1992 [14]. 
Війна в Хорватії тимчасово зупинилася в січні 1992-го встановленням напруженого недружнього перемир'я між сторонами за спостереження ООН. У березні до країни було введено 12-тисячний міжнародний контингент миротворців. На той час представники спільноти боснійських сербів під проводом Р. Караджича були готові протистояти незалежності Боснії й Герцеговини. Ще на початку 1991 року більшість боснійських хорватів та мусульман під керівництвом президента А. Ізетбеговича проголосували за незалежність [15, р. 332]. Діючи на випередження, сепаратисти - прихильники Р. Караджича заснували в країні незалежну Сербську Республіку (Сербска Крайна). Боснія офіційно вийшла зі складу Югославії в березні 1992-го і відразу розпочалися важкі бої. Парамілітарні сили Сербської Крайни за прямої допомоги ЮНА успішно розвивали наступ і протягом кількох тижнів під їхнім контролем опинилися майже дві третини території країни. Боєздатність боснійської армії була невисокою, через ембарго ООН ӥй на початку війни бракувало озброєнь.

Інтенсифікація насильства в Боснії та Герцеговині навесні 1992-го стимулювала прагнення європейців поставити ситуацію під контроль. Водночас країни-члени НАТО, як і інших міжнародних організацій - ОБСЄ, ООН спрощували характер конфлікту - щоби можна було зробити свої дії або бездіяльність зрозумілими для громадської думки. Найпростішим було покласти всю відповідальність на місцевих сербів у кожній охопленій війною країні та Белград, який справді стояв за ними. С. Милошевича небезпідставно звинувачували в «систематичному просуванні сербського проєкту шляхом застосування насильства, включно з етнічними чистками, встановлення нових кордонів, відповідно до меж проживання етнічно однорідних сукупностей населення на сусідніх з Сербією (невизнаною ФРЮ. - Авт.) територіях», а населені сербами землі в підсумку мали 6 увійти до складу Великої Сербії [16, р. 170].

Обвинувачення проти сербів формулювали в низці офіційних заяв. 11 травня Рада міністрів ЄС поклала відповідальність за насильство в Боснії-Герцеговині на ЮНА і владу в Белграді. Днем пізніше, у Декларації по Боснії-Герцеговині ОБСЄ засудила Белград та ЮНА за «очевидні, грубі і постійні порушення» принципів і зобов'язань ОБСЄ. 15 травня резолюція Ради Безпеки ООН № 752 засудила зовнішнє втручання в боснійські справи й запропонувала негайно припинити бойові дії [17]. 20 травня Державний департамент США закликав увести санкції у відповідь на «сербську агресію, що триває». Така інтерпретація подій, мабуть, не була помилкою, але в результаті вона призвела до однобічного підходу, згідно з яким у продовженні війни звинувачували майже виключно сербів. Це не відповідало дійсності, але згуртувало міжнародну спільноту, без чого дії ООН та участь НАТО були 6 неможливими. Вирі- 
шальний вплив на утвердження такого підходу мав обстріл Сараєва 27 травня 1992 року [16, р. 170-171], який призвів до загибелі 16 людей та 140 поранених.

ЄС і Сполучені Штати відреагували миттєво й увели санкції проти ФРЮ. РБ ООН підтвердила економічні санкції наступного дня. Резолюція РБ 757 від 30 травня 1992 року практично тимчасово виключила Сербію з міжнародної спільноти - до повного припинення атак проти Сараєва. Ця резолюція також запропонувала забезпечити дотримання економічних санкції проти ФРЮ та ембарго на постачання зброї до всіх регіонів колишньої Югославії [18]. До честі держсекретаря США Дж. Бейкера треба згадати, що на цей епізод він відповів пропозицією розглянути можливість військової інтервенції в межах «Плану гри: нові кроки у зв'язку з подіями в Боснії, який мав би забезпечити доступ гуманітарної допомоги до Сараєва «всіма можливими засобами». Президент Дж. Буш спочатку підтримав Дж. Бейкера, але План наштовхнувся на незгоду з боку міністра оборони Р. Чейні та генерала К. Пауела, голови Спільного комітету начальників штабів США. Хоча останнє слово мало б бути за президентом, обструкція військової верхівки унеможливила навіть підготовку техніко-економічного обгрунтування цього Плану. Так невдачею закінчилася запізніла спроба Дж. Бейкера втрутитися в події на Балканах. Згодом він очолив кампанію з переобрання Дж. Буша на другий термін, а на чолі державного департаменту його заступив Л. Іглбергер [8, p.173].

13 серпня РБ ООН одноголосно прийняла резолюцію № 771, яка засудила порушення міжнародного гуманітарного права в Боснії-Герцеговині й доручила відстежувати такі випадки. Згідно з експертним оцінюванням Альянсу, можна припустити, що сили вторгнення для припинення війни в Боснії мали 6 налічувати щонайменше 460 тисяч військовослужбовців, зокрема 200 тисяч американців. Ані адміністрація президента Дж. Буша, ані європейські союзники з НАТО не вважали, що їх інтереси вимагають вдатися до витратної, небезпечної для їх збройних сил масованої наземної операції [16, р. 170-171]. У. Зіммерман, посол США в Югославії, вважав, що «застосування сили було надто великим кроком, щоб тоді його навіть розглядати» [6, p. 158]. У своєму так званому «різдвяному» прощальному посланні від 23.12.1992 Дж. Буш-старший писав: «Політика уряду ФРЮ (Сербія і Чорногорія) на підтримку груп, що намагаються силою та насильством захопити території в Хорватії та Боснії-Герцеговині, та участь [Белграда] у цих діях продовжують представляти надзвичайну загрозу національній безпеці та економіці Сполучених Штатів. США залишаються відданими багатосторонньому розв’язанню кризи шляхом імплементації резолюцій ООН щодо ФРЮ» [19]. 
Ще на початку літа 1992 року мандат ЮНПРОФОР було поширено на Боснію-Герцеговину. Мета розміщення миротворців спочатку формулювали як підтримку наданню гуманітарної допомоги. Втім, їхня місія неухильно розширювалася, згодом включала оборону аеропорту Сараєво, супровід гуманітарних конвоїв, спостереження за припиненням вогню, моніторинг «безпечних зон» та стримування локальних нападів. У липні 1992 р. на прохання ООН НАТО погодилася моніторити доставлення вантажів по Дунаю та вздовж Адріатичного узбережжя (операція Отранто, разом зі ЗЄС, згодом - Морська варта, а з 15 червня 1993 року - Гостра Варта) для забезпечення економічного ембарго, а в листопаді мандат був розширений до формату «Зупинка та обшук» суден [20].

Військово-повітряні сили НАТО було долучено до регіону влітку 1992 року. Спочатку була задіяна система попередження та управління повітряним рухом для контролю за дотриманням ембарго на постачання зброї до країн, що утворилися внаслідок розпаду СФРЮ. Ця система також використовувалася для контролю економічних санкцій проти Белграда, накладених РБ ООН у відповідь на його агресію проти Боснії. Безпосередня співпраця між ООН та НАТО розпочалася 16 жовтня 1992 року коли РБ ООН резолюцією 781 заборонила несанкціоновані польоти військової авіації [21], а НАТО активізувала операцію «Контроль неба» (Sky Watch) для спостереження та інформування про порушення цієї заборони. Після фіксації сотень таких порушень протягом наступних кількох місяців, головним чином сербськими літаками, 31 березня 1993 року РБ ООН схвалила резолюцію 816, що забороняла польоти військової авіації без спеціального дозволу ООН та надала дозвіл НАТО збивати літаки, що порушують цю заборону [22]. Для іiі реалізації НАТО замінило «Контроль неба» операцією «Заборона польоту» (Deny Flight), яка передбачала новий рівень застосування сили. У подальші місяці ООН та НАТО додали низку інших функцій цій операції: пряма повітряна підтримка для оборони персоналу $\mathrm{OOH}$, який піддано атаці; наступальна авіаційна підтримка для покарання порушників резолюцій РБ ООН; знешкодження протиповітряної оборони противника для оборони авіації НАТО, що виконує свої завдання в координації з ООН. У такий спосіб еволюціонував процес, який заклав основи операції «Звільнена сила» (1995р.), яка з військово-технічного погляду була власне найвищою фазою «Заборони польоту» [15, р. 461]. Наприкінці грудня 1992 року НАТО знову підтвердила свою незгоду на розгортання військ Альянсу в Боснії та Герцеговині. Відмова розглядати військові засоби, які були єдиним можливим шляхом пацифікації ситуації, суперечила наданій міжнародними структурами оцінювання становища в країні. Замість рішучих дій була довга серія паліативно-імітаційних кроків - схвалення, за підрахунками К. Нейшна, до грудня 1993 року не менше 54 резолюцій 
РБ ООН із конфліктів у колишній Югославії, уведення санкцій, ембарго, спрямування майже неозброєних миротворців до країни, у якій тривала війна. Відбувалися візити естрадних зірок до напівзруйнованого Сараєва, лунали порожні погрози, зовнішні актори вдавалися до нескінченних спроб посередництва - усе це створювало звуковий супровід, викликало роздратування безпосередніх учасників конфлікту, населення та «занепокоєння» міжнародного співтовариства, але жодним чином не стримувало динаміку збройного конфлікту [16, p.172].

Командувач ЮНПРОФОР французький генерал Ф. Морильйон під час візиту до мусульманського анклаву Сребренице 11 березня 1993 року узяв на себе ініціативу й особисто оголосив місто «безпечним районом» під захистом ООН. У червні того самого року ООН схвалила надання такого статусу Сараєву, Горажде, Сребрениці, Тузлі, Жепі та Біхачу. На ділі термін «безпечний район» був евфемізмом, який використовувався щодо незахищених анклавів, які перебували у ворожій облозі. Вони були переповнені біженцями, чисельність яких разом із місцевим населенням становила понад 1,2 мільйона осіб. Беручи на себе відповідальність за захист «безпечних районів», підрозділи ЮНПРОФОР не мали засобів збройної боротьби для виконання цієї функції та не набули їх до кінця війни в Боснії та Герцеговині [23].

Незважаючи на ембарго, зброя, набої, пальне та мастила надходили до комбатантів. Ба більше, звичайною практикою були бартерні оборудки необхідним між сторонами протистояння. ЮНПРОФОР розчаровували конфліктами серед командування, їм бракувало надійних розвідданих та зв'язку на оперативному рівні. Директивні обмеження з боку ООН унеможливлювали виконання функції підтримання миру. У період із квітня 1992 до травня 1994 р. було укладено майже 77 угод між сторонами протистояння про припинення вогню під егідою оонівських посередників, усі вони виявилися ефемерними [16, р. 173]. Чисельність ЮНПРОФОР у Боснії та Герцеговині зросла з 1500 військовослужбовців у серпні 1992-го до понад 23000 у 1995 році, але їх бракувало для оборони «безпечних зон» та для примушення до миру.

У грудні 1992 року ООН схвалила створення третього (після Хорватії та Босніі) командування ЮНПРОФОР - у Македонії, миротворці розташувалися уздовж кордонів із Косовом, Албанією та Сербією й мали запобігти поширенню війни на цю країну. 315 американських солдатів приєдналися до контингенту ЮНПРОФОР у Македонії влітку року. Уперше військовослужбовці США долучилися до операції під командуванням $\mathrm{OOH}$ у Європі. Ці ініціативи поглибили міжнародну співпрацю в колишній Югославії, але були неспроможні припинити війни. За браком консенсусу щодо пріоритетів місії, обмеженість мандату та прагнення уникати 
ризиків втрат персоналу військових контингентів призвели до ії неефективності. Превентивне розгортання військ у Македонії стабілізувало ситуацію, ствердило позиції Скоп'є, але водночас надало Белграду привід зображати їх діями з безпідставного стримування за браком реальної загрози цій країні з боку ФРЮ.

Під час передвиборчої кампанії 1992 року Б. Клінтон активно критикував «неополітику» Дж. Буша щодо боснійської кризи, але політика невтручання тривала й після приходу президента-демократа до Білого дому. У травні 1993 року адміністрація розпочала деякі дипломатичні кроки у відносинах із союзниками з проблем війни в Боснії-Герцеговині. Відбувся візит державного секретаря У. Кристофера до штаб-квартири НАТО. Європейці були здивовані, коли замість пропозиції власного лідерства Сполучені Штати заявили про «консультативний» та миротворчий характер його місії. Зважаючи на вагу Сполучених Штатів в Альянсі, це на тривалий час паралізувало масштабну ініціативу НАТО в Боснії та Герцеговині [24, p. 47-48].

На саміті НАТО 10-11 січня 1994 року в Брюсселі, який відвідав Б. Клінтон, констатували неефективність дій міжнародного співтовариства. У комюніке за результатами саміту НАТО вкотре загрожувала боснійським сербам повітряними ударами, якщо вони не припинять облогу Сaраєва. Також висували вимогу надати можливість ротації миротворців ООН (голландці мали заступити канадців) у Сребрениці, блокованій армією боснійських сербів, та використання аеропорту Тузла для надання гуманітарної допомоги ООН [8, p. 181].

У січні 1994 року керівники боснійських мусульман і хорватів під егідою США зустрілися в Петерсберзі поблизу Бонна, а трьома місяцями пізніше, 18 березня 1994 року у Вашингтоні було оголошено про створення Боснійської хорватсько-мусульманської федерації. (Формальне запрошення було надіслано й сербам, але вони його відкинули.) Це поклало край війні між хорватськими та мусульманськими силами в центральній частині Боснії та Герцеговини, яка тривала близько року, але нові союзники виявилися нездатними об'єднати свої збройні сили для війни проти боснійських сербів та ЮНА, яка стояла за ними [25]. 5 лютого 1994 року на ринку в Сараєво внаслідок мінометного обстрілу загинули 65 і було поранено понад 200 осіб. Сербські речники негайно відреагували: це влаштували самі мусульмани, щоби привернути на свій бік симпатії світової громадськості. Точну відповідальність за обстріл встановити не вдалося. Генерал М. Роуз, командувач ЮНПРОФОР у Боснії та Герцеговині заявив, що аналіз воронки від вибуху не дає змогу зробити висновок щодо траєкторії міни. Ясуші Акаші, спеціальний посланник Генерального секретаря ООН у Боснії та Герцеговині, поділяв його погляд. Втім, акт насильства цілком вкладався в схему довготривалих обстрілів Сараєва боснійськими 
сербами. Цього виявилося достатньо для гострої міжнародної реакції [26]. Трагедія Сараєво прибрала бар'єри на шляху активізації НАТО. 7-го лютого Альянс виступив з ультиматумом: у 10-денний термін усі сербські важкі озброєння й міномети мають бути виведені з двадцятикілометрової «виключної зони» навколо Сараєво. Також сербам доручалося під контролем ЮНПРОФОР створити дев'ять пунктів зберігання такої зброї за межами «зони». Після складних переговорів боснійські серби погодилися виконати вимоги НАТО, але за умови передислокації до Сараєва приблизно 400 російських військовослужбовців зі складу контингенту ЮНПРОФОР у Хорватії. Втручання НАТО змусило діяти Москву, вона не бажала поступитися в Боснії Альянсу, який вважався нею опонентом у міжнародних справах. Теоретично співпраця з росіянами розширяла фундамент миротворчих зусиль, але вона додала чимало проблем через необхідність постійно узгоджувати дії в Боснії з позицією Кремля. 3 погляду Москви, вона здобула неабияку дипломатичну перемогу: «Серби не поступилися ультиматуму Заходу, але були готові прислухатися до свого традиційного російського друга» [27]. Невдовзі сподівання боснійських сербів на російську допомогу розвіялися. У лютому-березні 1994-го, завдяки імпульсу, наданому відходом сербів з околиць Сараєва, вдалося відновити роботу аеропорту Тузла, контролювали цей процес російські спостерігачі. Це мало велике стратегічне значення не тільки для доставляння гуманітарної допомоги. Тузла постала бастіоном підтримки єдиної багатонаціональної Боснії-Герцеговини. 27 лютого 1994 року два літаки НАТО збили чотири реактивних винищувачі ЮНА Яструб, які порушили заборонену для польотів зону поблизу Баня-Луки. Це були перші бойові дії Альянсу з моменту його створення в 1949 році. 10-12 квітня авіація НАТО завдала трьох суто символічних повітряних ударів по позиціях сербів під час боїв за анклав Горажде. 22 квітня (Горажде все ще перебувало в облозі сербських підрозділів) миротворці зобов'язалися обороняти «безпечні райони» Жепа, Тузла, Біхач і Сребрениця. Сербська атака на французьку бронемашину під час боїв навколо Сараєва призвела до удару сил НАТО у відповідь по протитанковій установці всередині «виключної зони» 22 вересня. 21 листопада авіація НАТО завдала удар по авіабазі Удбіна в Кнінській Крайні, з якої серби атакували Біхач, і заподіяла їм відчутних втрат. 23 листопада було завдано авіаударів по радарах (але не пускових установках) на трьох сербських об’єктах ППО в районі Біхача [16, р. 183]. У березні-квітні 1994 року серби розпочали новий наступ на «безпечну зону» - найбільший мусульманський анклав Горажде. У середині квітня Горажде опинився в зоні досяжності артилерійського вогню сербів і на межі падіння. 23 квітня Ясуши Акаші, занепокоєний долею військовослужбовців ЮНПРОФОР всередині анклаву, відхилив пропозицію Гене- 
рального секретаря НАТО М. Вернера використати авіацію, щоби примусити сербів відступити. 26 квітня сербські сили почали відхід із власної ініціативи - у генерала Младича просто бракувало піхоти, щоби подавити укріплені точки ворога [28, p. 150]. Осада Горажде знов продемонструвала вразливість «безпечних районів» та відсутність належної взаємодії командування ЮНПРОФОР і НАТО. Влітку 1994 року обидві місцеві сторони конфлікту множили порушення «зони відчуження» навколо Сараєва, а в серпні-вересні тут розгорнулися жорстокі бої. Дії боснійських сербів, які неодноразово намагалися завадити роботі аеропорту Сараєво й перекрити єдиний шлях із міста до бази матеріально-технічного забезпечення ООН у Кіселяку, кинули виклик миротворчій місії ООН у Боснії та Герцеговині. Неодноразово командувач ЮНПРОФОР М. Роуз загрожував сторонам протистояння повітряними ударами за порушення «зони відчуження». У той саме час мусульманські та хорватські війська вибили сербів із низки населених пунктів у центральній Босніі. У липні вони придушили опір сербів у районі Біхача та їх примусили відійти до Сербської Крайни. Розвинути успіх ворогам сербів не вдалося через успішний контрнаступ противника. 3 новою силою спалахнули дискусії серед західних союзників щодо застосування авіації НАТО для захисту «безпечних районів» у ворожій облозі. Принциповим опонентом був генерал М. Роуз. Тоді кризу вдалося врегулювати, серби відступили, але проблема не зникла. Наприкінці травня 1995 року авіація НАТО здійснила кілька нальотів на військові об’єкти боснійських сербів для того, щоб примусити їх до припинення вогню у «виключній зоні» Сараєво. У відповідь серби захопили в заручники майже 400 миротворців ООН. Деяких із них прикували ланцюгами до потенційних цілей для натівських авіаударів як живий щит [28, p. 45] (виключно на потрібний для фотографування час). Ці пропагандистські світлини публічного приниження військових-миротворців широко розійшлися у світових 3МI і стали не тільки наочним свідченням безсилля ЮНПРОФОР, але й каталізатором подальшої зовнішньої інтервенції у війну в Боснії й Герцеговині. Звільнити з полону миротворців-заручників вдалося завдяки втручанню С. Милошевича. НАТО припинила авіаудари. 3 червня міністри оборони чотирнадцяти країн-членів ЄС та НАТО узгодили створення Сил швидкого реагування для захисту миротворців із ЮНПРОФОР, а наприкінці липня британсько-французький контингент було переведено з центральної Боснії на гору Ігман, критично важливий пункт на сараївському фронті. Одним із безпосередніх наслідків цих бомбардувань постав тимчасовий перехід політичного керівництва збройним втручанням від ООН до так званої Контактної групи. Сформована ще влітку 1994 року контактна група складалася з міністрів закордонних справ США, Великої Британії, Франції, Німеччини та Росії. Єдиною ціллю групи 
було надання альтернативного ООН механізму для переговорів про мирне врегулювання в регіоні. Під час передвиборної кампанії в США республіканці, які контролювали Конгрес, проголосували, всупереч позиції адміністрації Б. Клінтона, за відміну ембарго на постачання зброї уряду БосніїГерцеговини. Головні європейські союзники з НАТО негайно відреагували: вони відмовляться від своїх зобов'язань у межах ЮНПРОФОР у разі, якщо американці, не маючи сухопутних військ на театрі воєнних дій, які щоденно наражаються на смертельну небезпеку, розпочнуть постачання зброї одній зі сторін протистояння. Адміністрація США була налаштована на уникнення будь-яким через направлення своїх військовослужбовців для участі в операціях на суходолі в Боснії в складі ЮНПРОФОР, Сил швидкого реагування або НАТО, адже людські жертви загрожували електоральними втратами. У такий спосіб загрожувала б і відмова Білого дому взагалі від втручання у війну в колишній СФРЮ. 11 липня боснійські серби захопили «безпечний район» Сребрениця. Треба визнати, що з неї час від часу відбувалися збройні рейди мусульманських загонів до сербських сіл, під час яких мирне населення підпадало під репресії, включно з убивствами. Але це жодним чином не виправдовує масову різанину, яку вчинили серби в Сребрениці, нечувану в Європі з часів Другої світової війни. Спочатку з «безпечного району» вони витіснили 429 голландських блакитних шоломи, потім протягом кількох діб жорстоко вбили понад 8000 осіб. В очах світової спільноти це остаточно дискредитувало цілі, що їх переслідували боснійські серби у війні. Кровопролиття липня 1995 року стало можливим через некваліфіковане управління ЮНПРОФОР, командування яких заборонило своєчасне превентивне застосування повітряних нападів НАТО. Загалом «безпечні зони» ніколи насправді не були безпечними. Слідом за Сребреницею, 25 липня впав анклав Жепа, який безсилі були захистити 68 українських блакитних шоломів [16, p. 191]. На черзі був великий анклав Горажде, але, як виявилося, серби перетнули межу, за якою бездіяльність НАТО не могла тривати. На засіданні 26 липня в Брюсселі Північноатлантична рада заявила, що вдасться до «швидких та ефективних» дій у разі нападу на Горадже. Серби відступили. Після років мінімальних символічних кроків рішення НАТО «завдати важкого удару» в Боснії та Герцеговині було здійснено надзвичайно швидко. Така раптова драматична зміна після місяців бездіяльності Альянсу (навіть зважаючи на звірства в Сребрениці та Жепі), на думку Р. Холбрука та його колег у місії в колишній Югославії, відбулася через дію чотирьох чинників: відчуття, що далі таке продовжуватися не повинно; емоційна реакція Вашингтона на втрату трьох американців - колег Р. Холбрука на горі Ігман; особиста рішучість президента Б. Клінтона покласти край війні; та тверда рекомендація очолюваної Р. Холбруком команди перемовників: бомбардування мають від- 
буватися незалежно від їх впливу на перебіг переговорів. 3 погляду європейців, це питання мало інший вигляд. У минулому вони завжди були проти масованих бомбардувань, бо побоювалися, що їхні солдати потраплять у заручники до сербів. Останній британець покинув анклав Горажде, де була найбільша загроза, в останній момент до початку бомбардувань. Але багато інших миротворців $\mathrm{OOH}$ у різних «безпечних районах» залишалися вразливими, отже, тривав опір операції НАТО, навіть коли вона вже почалася. У Холбрука не було сумнівів, що європейці заблокували 6 або мінімізували бомбардування, якби не рішучість Вашингтона йти до кінця. Незгода між союзниками з НАТО стосувалася тривалості нальотів та об'єктів застосування зброї, отже, потрібний був тиск, щоби не змарнувати витрачених зусиль [4, p. 176].

«Звільнена сила» (Deliberate Force) - перша в історії НАТО військовоповітряна операція - розпочалася 30 серпня та ії початковий етап тривав три дні - до 2 вересня 1995 року. Другий етап: 5-14 вересня. 2 вересня генерал Б. Жанвер, командувач ЮНПРОФОР у Боснії запропонував зробити паузу, щоби дати змогу боснійським сербам виконати три вимоги: (1) припинити напади на Сараєво та «безпечні зони»; (2) відвести всі важкі озброєння на відстань 20 км від Сараєва; (3) надати необмежений доступ та свободу пересування персоналу ООН та інших гуманітарних місій. Коли серби не виконали повністю цих вимог, повітряні удари відновилися. Задіяні до операції багатонаціональні сили Альянсу складалися з понад п’яти тисяч військовослужбовців 3 п’ятнадцяти країн, а безпосередніх ударів завдавала авіація восьми держав - США (68\%), Велика Британія (10\%), Франція (7\%), Нідерланди (6\%), Іспанія (4\%), Туреччина (3\%), Італія (1\%), Німеччина (1\%) [15, p. 459]. Усього було виконано 3535 бойових вильоти, 3 них 2470 у повітряний простір Боснії та Герцеговини (36\% з них для ударів по наземних цілях), інші - у суміжні простори. Усього по 48 комплексах об’єктів (цілей) було застосовано 1026 бомб та ракет - з них 69\% високоточних. Більше 400 літаків злітали з 18 авіабаз у п’ятьох країнах, насамперед Італії, та чотирьох авіаносців у Адріатичному морі. Додатково з військового корабля було завдано одного разу удару ракетами «Томагавк». Тринадцять цих коштовних радіокерованих ракет атакували важливі військові об’єкти в західній частині Боснії - районі Баня Луки, далеко від Сараєва та Горажде. Хоча кілька боєзарядів по сім сотень фунтів вибухівки не були такими ж потужними, як сотні двохтисячних авіабомб, скинутих під час операції, психологічний ефект застосування сучасної зброї, яку до цього використовували лише у війні в Затоці 1991 року, був величезним. Удар мав і прямий воєнний результат: один із «Томагавків» зруйнував головний Центр комунікацій армії боснійських сербів на заході країни [4, p. 238]. Ці удари викликали неоднозначну реакцію в НАТО. 11 вересня на спеціально- 
му засіданні Північноатлантичної ради Франція, Іспанія, Канада та Греція критикували напади в західній Боснії, стверджуючи, що це несанкціонована ескалація. Категоричну незгоду з розвитком операції висловлювала Москва. Ще 7-го вересня Б. Єльцин написав президенту Б. Клінтону, що він занепокоєний бомбардуваннями. Але справжній вибух московських протестів відбувся через використання крилатих ракет «Томагавк». Росіяни патетично проголосили, що не можуть «бути байдужими до долі дітей наших друзів-слов'ян». (Пентагон негайно заперечив: унаслідок повітряних ударів не загинула жодна дитина.) Російські дипломати погрожували вийти зі складу Контактної групи. Міністр оборони РФ П. Грачов попередив В. Перрі: удари можуть призвести до перегляду Москвою угод про військову співпрацю з НАТО та погрожував, якщо бомбардування не припиняться, «допомогти сербам в односторонньому порядку». Наступного дня Росія запропонувала резолюцію Ради Безпеки ООН про засудження бомбардувань, але посол М. Олбрайт їі блокувала. НАТО не могла повністю ігнорувати реакцію Москви, тому що Перрі та Грачов уже розпочали перемовини щодо участі Росії в спільній з Альянсом майбутній місії в Боснії - після припинення бойових дій. Водночас тривала дискусія з питання розширення НАТО. Для врегулювання спірних питань до Москви негайно вилетів С. Телбот, поїздка виявилася своєчасною та ефективною. Після пояснень причин, з яких бомбардування важливі для встановлення миру, російські претензії хоча й не були повністю усунуті, але їх тон знизився. Шлях до подальших переговорів Перрі з Грачовим було відкрито [4, p. 239-240].

Чотирнадцять тижнів, які передували припиненню війни в Боснії, були сповнені конфліктів, плутанини та трагедій, перш ніж призвести до дипломатичного успіху. «Переговори, - за словами Р. Холбрука, - поєднували інтелектуальні змагання та силовий тиск, у діапазоні від абстрактних категорій до особистих якостей, щось на зразок поєднання шахів та альпінізму. Це була не інтелектуальна гра між державами, а небезпечний шлях 3 непередбачуваними поворотами та наслідками» [4, p. 17].

За тиждень до початку бомбардувань ООН почала поступово відводити підрозділи «голубих шоломів» і зосередила їх на захищених позиціях. Цей процес завершився ще до початку авіаударів. Під час бомбардувань ці сили займали свої позиції, проводили обмежене патрулювання, але не йшли в наступ - на відміну від боснійських мусульманських та хорватських військ, які намагалися якнайкраще використати ситуацію й повернути раніше захоплені сербами територіі. Підрозділи Сил швидкого реагування, розташовані в районі Сараєва із середині червня, під час перших двох діб операції підпадали під артобстріли позиції боснійських сербів, але серйозного впливу на перебіг подій це не справило у порівнянні з авіаударами та наступом боснійців. 
Загрози успішному завершенню операції виникли з неочікуваного напряму. На нараді в президента Б. Клінтона 11 вересня міністр оборони B. Перрі раптом запропонував зробити другу перерву в бомбардуваннях тоді, коли вони відбувалися найінтенсивніше. Водночас військові пропонували, у разі продовження операції, використовувати ракети «Томагавк» та літак F-117, найкраще захищений від виявлення радарами ворога. ВМФ та ВПС хотіли продемонструвати бойові якості своєї найсучаснішої зброї. Політичне рішення було - продовжити операцію [4, p. 242]. 12 вересня з'ясувалося, що віцеадмірал Л. Сміт має нові цілі приблизно на три доби бомбардувань, а тільки потім може повернутися до повторних ударів по вже вражених цілях. Отже, він самотужки визначатиме, коли бомбардування втратять сенс. За оцінюванням Р. Холбрука, «це навряд чи було найкращим способом поєднання дипломатії та військового тиску» [4, p. 244].

Отже, Р. Холбрук блефував, коли обіцяв тривалі бомбардування сербських позицій, але до його слів прислухалися, оскільки до літа 1995 року він набув репутації провідної особи - представника Контактної групи в колишній СФРЮ. Його невеличка команда американських дипломатів і військових проводила надзвичайно інтенсивні прямі човникові переговори із С. Милошевичем, Р. Караджичем, А. Ізетбеговичем, іншими лідерами ворогуючих сторін, Брюсселем та Вашингтоном під час операції «Звільнена сила». Вимагаючи потужних бомбардувань, Холбрук прагнув припинити війну в Боснії й Герцеговині. Втім, ініціюючи цю операцію, Північноатлантична рада офіційно проголосила ії метою захист так званих «безпечних зон» й більше. Досягнутий у Раді консенсус із питання повітряно-військової операції був тільки на рівні підтримки відповідних резолюції РБ ООН.

Високоточні бомбардування дали змогу мінімізувати небажані втрати серед населення. Операція НАТО досягла мети: припинити атаки боснійських сербів на так звані «безпечні зони», примусити їх відвести важкі озброєння з низки місць, припинити облогу Сараєва, а в підсумку вдалося переконати (хоча й не одразу) усі ворогуючі сторони припинити бойові дії й погодитися з умовами, викладеними в рамковій угоді, яка зрештою призвела до Дейтонських мирних угод, що сприяло загальному мирному процесу на Балканах.

Нальоти авіації НАТО, хоча й не узгоджувалися з діями мусульманських та хорватських наземних сил, але допомагали їхньому наступу. У результаті операції та успіхів мусульман та хорватів у наземній війні виникли реальні передумови збереження єдиної країни, територіально поділеної в співвідношенні 51/49 відсотків між мусульманами й хорватами, з одного боку, та сербами - з іншого, як і передбачалося мирним планом Контактної групи. Переговорний процес став можливим і тому, що С. Милошевич ще 1994 року оголосив про відмову боснійським сербам у подальшій еконо- 
мічній допомозі, закрив кордон, але військова допомога тривала (перебіг подій відтоді показав, що позиція Белграда в цьому питанні не відрізнялася послідовністю), а Росія загалом зайняла нейтральну позицію. «Нам ніколи не дозволялося називати (операції в Югославії. - Авт.) війною, писав генерал В. Кларк. - Але, звичайно, це була війна. Перша війна за останні 50 років в Європі й перша війна, яку вела НАТО. Альянс або якась із країн-членів не були атаковані ворогом. Не йшлося про виживання держав (членів НАТО. - Авт.) або демократичної системи. Ми не оголошували мобілізацію та не обмежували діяльність ЗМІ. Солдати-призовники й не наближалися до театру воєнних дій, тому що в більшості країн НАТО законом заборонялася їхня служба поза національної території. Не відбувалася перебудова економіки на воєнний лад або уведення державного контролю над нею. Дуже ретельно обиралися види зброї для використання і цей процес не було покладено на військових. Населення та суто цивільні об’єкти не обиралися як цілі для нанесення ударів. Це була сучасна війна - обмежена за масштабами та театром воєнних дій, використаними озброєннями та наслідками» [28, p. XXXVII- XXXVIII].

Наприкінці перемовин у Дейтоні С.Милошевич звернувся до В. Кларка: «Отже, генерал, можете бути задоволеним, НАТО виграло цю війну (в Боснії та Герцеговині. - Авт.)». «М-р президент, - відповів Кларк, - НАТО навіть не воювала. Ви програли їі хорватам та мусульманам». Звичайно, Кларк не казав правду. Дії НАТО сприяли військовим перемогам, унаслідок яких було звільнено захоплені боснійськими сербами під час війни території. Милошевич мав рацію, коли не погодився: «Це була ваша НАТО, ваші бомби та ракети, ваші високі технології, які нас розбили. Ми, серби, ніколи не мали шансів (на перемогу. - Авт.) проти вас» [28, р. 67]. Але Милошевич «не пам'ятав», скільки сигналів про припинення війни, надісланих РБ ООН, він проігнорував, перш ніж відбулося масштабне збройне втручання НАТО.

У разі, якщо введення миротворчого міжнародного контингенту до окупованих Російською Федерацією окремих районів Донецької та Луганської областей України набуде реальних контурів, Києву, на нашу думку, потрібно найретельнішим чином вивчити фактичний бік подій у колишній СФРЮ. Це мало 6 допомогти уникнути багатьох ускладнень, що виникали в процесі здійснення операції з примушення до миру на Балканах у першій половині 90-х років XX століття.

1. The International Tribunal for the Prosecution of Persons Responsible for Serious Violations of International Humanitarian Law Committed in the Territory of the Former Yugoslavia since 1991 [Електронний ресурс]. - Режим доступу: https://www.icty.org/x/file/Legal\%20Library/Statute/statute_sept09_en.pdf.

2. West R. Black Lamb and Grey Falcon. - New York, N.Y.: Penguin Books, 2005. - 1196 p.

3. Kaplan R. Balkan Ghosts: A Journey Through History / R. Kaplan. - New York, N.Y.: St. Martin's Press, 1993. - 384 p.

4. Holbrook R. To End a War, The Conflict in Yugoslavia-America's Inside Story-Negotiating with Milosevic. New York: Random House, 1999. - 648 p. 
5. Клинтон У. Дж. Моя жизнь. - М.: Альпина, 2005. - 1088 с.

6. Zimmermann W. Origins of a Catastrophe: Yugoslavia and its Destroyers--America's Last Ambassador Tells What Happened and Why. New York: Random House, 1996. - P.216.

7. Cohen B. With No Peace to Keep: United Nations Peacekeeping and the War in the Former Yugoslavia/ B.Cohen and G.Stamkovski, eds. -London: Grainpress Ltd., 1995. - 389 p.

8. Klemenčič M. The International Community and the FRY Belligerents, 1989-1997. Confronting the Yugoslav Controversies. A Scholars' Initiative. Ed. by Charles Ingrao and Thomas A. Emmert. - West Lafayette, Indiana: Purdue University Press, 2009. - 444 p.

9. Baker J. The Politics of Diplomacy/ James A. Baker III, with Thomas M. DeFrank. - New York, N.Y.: G. P. Putnam's Sons, 1995. $-687 \mathrm{p}$.

10. Gompert D. The United States and Yugoslavia's Wars/D.Gompert, in The World and Yugoslavia's Wars, Richard H. Ullman, ed. - New York, NY: Council on Foreign Relations, 1996. - 360 p.

11. Silber L. Yugoslavia: Death of a Nation / L.Silber and A.Little. - London: Penguin Books/BBC Books, 1996. - 264 p

12. UN SC Res. 713 25.09.1991 [Електронний ресурс]. - Режим доступу: https://documents-dds-ny.un.org/doc/RESOLUTION/GEN/NR0/596/49/IMG/NR059649.pdf?OpenElement

13. UN SC Res 724 15.12.1991 [Електронний ресурс]. - Режим доступу: https://documents-dds-ny.un.org/doc/RESOLUTION/GEN/NR0/597/44/IMG/NR059744.pdf?OpenElement

14. UN SC Res. 743 21.02.1992 [Електронний ресурс]. - Режим доступу: https://documents-dds-ny.un.org/doc/RESOLUTION/GEN/NRO/012/50/IMG/NR001250.pdf?OpenElement

15. Owen R. Deliberate Force. A case study in effective air campaigning : final report of the Air University Balkans air campaign study / Ed. by R. Owen. - Air University Press Maxwell Air Force Base, Alabama, January 2000. - 536 p.

16. Nation C. War in the Balkans, 1991-2002 / C. Nation. - Carlisle, PA: Strategic Studies Institute, U.S. Army War College, 2003. -388 p.

17. UN SC Res. 75215.05 .1992 [Електронний ресурс]. - Режим доступу: https://documents-dds-ny.un.org/doc/RESOLUTION/GEN/NR0/011/11/IMG/NR001111.pdf?OpenElement

18. UN SC Res.757 30.05.1992 [Електронний ресурс]. - Режим доступу: https://documents-dds-ny.un.org/doc/RESOLUTION/GEN/NRO/011/16/IMG/NR001116.pdf?OpenElement

19. Letter to Congressional Leaders Reporting on Sanctions Against the Federal Republic of Yugoslavia (Serbia and Montenegro) December 23, 1992 // Public Papers of the Presidents of the United States: George Bush, 1992-1993[Електронний ресурс]. - Washington: GPO, 1993. - Р. 2213 - Режим доступу: https://www.gpo.gov/ fdsys/pkg/PPP-1992-book2/pdf/PPP-1992-book2-doc-pg2209-2.pdf

20. Cremasco M. Successes and Failures of International Institutions in the Post-Yugoslav Crisis. European Security and International Institutions after the Cold War. - Ed. by M. Carnavale. - New York, NY: St.Martin's Press, 1995. - 242 p.

21. UN SC Res.781 16.10.1992 [Електронний ресурс]. - Режим доступу: https://documents-dds-ny.un.org/doc/UNDOC/ GEN/N92/491/64/IMG/N9249164.pdf?OpenElement

22. UN SC Res.816 [Електронний ресурс]. - Режим доступу: https://documents-dds-ny.un.org/doc/UNDOC/GEN/ N93/187/17/IMG/N9318717.pdf?OpenElement

23. Ingrao Ch. Safe Areas. Confronting the Yugoslav Controversies. A Scholars' Initiative/ Ed. by Ch. Ingrao and Th. Emmert/ - West Lafayette, Indiana: Purdue University Press, 2009. - P. 200-229.

24. Hendrickson R. Diplomacy and War at NATO: The Secretary General and Military Action after the Cold War. - Columbia and London: University of Missouri Press, 2006. - 172 p.

25. Rudman G. Backtracking to Reformulate: Establishing the Bosnian Federation // International Negotiation, Vol. 1, No. 3, 1996. - pp. 525-545.

26. Boyd Ch. Making Peace with the Guilty: The Truth About Bosnia // Foreign Affairs, Vol. 74, No. 5, September-October 1995. - pp. 22-38;

27. Смирнова Н. Балканы и политика России: история и современность // Мировая экономика и международные отношения. - 1994. - № 5. - С. 110-116.

28. Clark W.. Waging modern war: Bosnia, Kosovo, and the future of combat. - New York: Public Affairs, 2002. - 479 p. 


\section{THE INTERNATIONAL CONTEXT OF WARS IN THE FORMER SOCIALIST FEDERAL REPUBLIC OF YUGOSLAVIA (1991-1995)}

Abstract. The article attempts to explain the reasons of the Yugoslav tragedy, which claimed about 300,000 lives and led to the displacement of more than 2 million people. The author boils the answer down to the simplified and biased Western interpretation of the influence of Balkan history on the situation after the collapse of the SFRY, systemic uncertainty in European and transatlantic relations after the end of the Cold War, adventurous and irresponsible behaviour of the leaders of several independent countries established on the ruins of the former SFRY, inadequate reaction of the US and NATO to the crisis, Europeans' false initial belief that they will be able to address security challenges in the 'new' Europe.

The author emphasizes that the settlement of the Yugoslav crisis should have immediately become NATO's priority. In such a case, Americans and Europeans could have started working together as mediators among different conflicting parties to ensure a peaceful 'divorce' of the republics. However, Washington did not want to see this. The US attitude to the Yugoslav crisis in 1990-1992 undermined the foundations of the declared policy of NATO's central role in Europe after the Cold War, which envisaged the responsibility of the Alliance for resolving the Balkan conflict.

The author argues that if the deployment of an international peacekeeping contingent in the Russian-occupied parts of Ukraine's Donetsk and Luhansk regions takes an expressive form, Kyiv will need to carefully examine the factual background of the events in the former SFRY. This should help avoid many of the complications that arose during the peace enforcement operation in the Balkans in the first half of the 1990s.

Keywords: NATO, Balkans, SFRY, Yugoslav tragedy, USA. 